\title{
Appreciation
}

\section{A tribute to an eminent public health hero - Dr. H M S S D Herath}

\author{
Stanley de Silva \\ Former Deputy Director General (ET \& R), Ministry of Health, Sri Lanka \\ DOI: https://doi.org/10.4038/jccpsl.v23i2.8125
}

Dr H M S S D Herath - popularly known as "Ananda", a past president and a member of the College of Community Physicians of Sri Lanka entered into rest with his Master and Lord peacefully on 4 June 2017 surrounded by his loving family members. He retired from the Ministry of Health as Deputy Director General (Public Health Services) in 1997.

Born on 3 October 1937, to a Christian teacher family, he had his primary and secondary education at Kingswood College, Kandy. Having entered, the then University of Ceylon in the year 1955 he passed out from the Faculty of Medicine University of Ceylon in 1961. Being the youngest student of the batch, he graduated with 2nd class Honours.

From the beginning of his medical career, he had a great attraction for public health practice and he served as Medical Officer of Health (MOH) Eheliyagoda from 1966 to 1968 . He was a great stalwart and a pioneer in the mass campaign to control poliomyelitis at that time with the newly introduced oral polio vaccine.

For the great interest shown by Dr. Herath towards public health, especially in the discipline of Environmental Health and as he opted for Public Health as a career, he was selected to follow the course leading to the Diploma in Tropical Public Health (DTPH) at the London School of Hygiene and Tropical Medicine in 1972. Having obtained DTPH (Lond.), he continued his studies at the same university and obtained the Diploma in Industrial and Occupational Health (DIH).

On his return to Sri Lanka, he was appointed as the Senior Medical Officer in Environmental and Occupational Health (SMO - E\&OH) in the Ministry of Health. Subsequently, he obtained MRCP (UK) and MRCP (Ireland). Later, he was honoured with FRCP

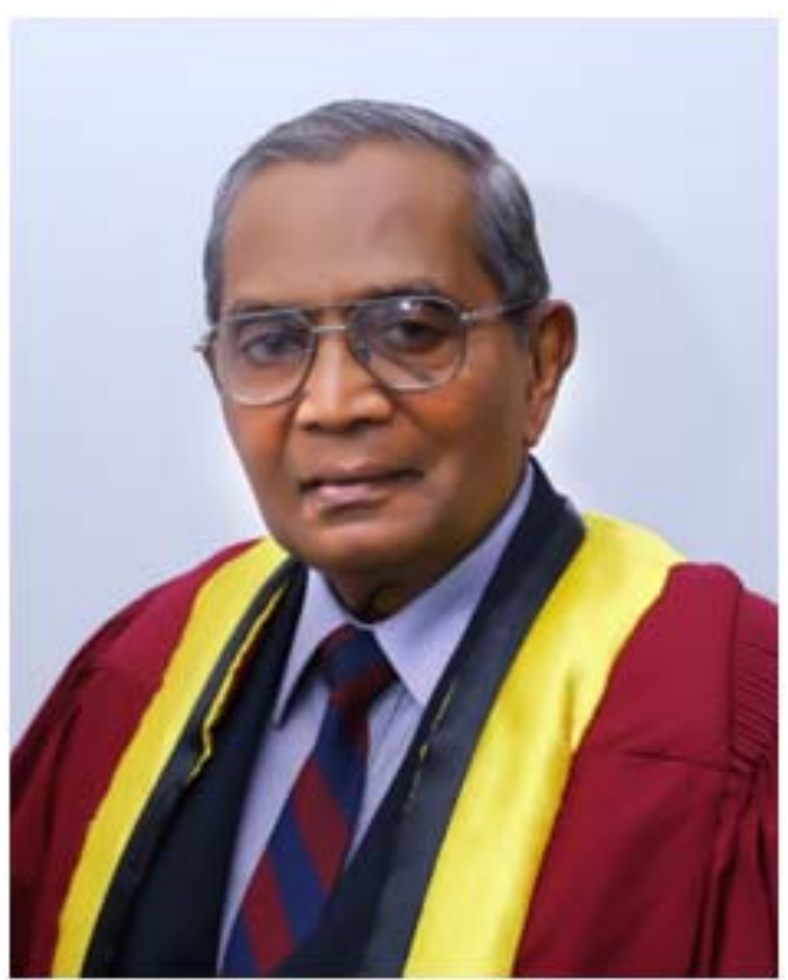

(Edin.) and MFOM (Lond.). However, since he has opted for Public Health, he remained in public health and became an eminent Community Medicine Specialist and an impartial Medical Administrator.

He was promoted to Director Environmental and Occupational Health (D-E\&OH) in the year 1987, and to the post DDG (PHS). He edited the manual of the Sri Lanka Public Health Inspector and the book on Occupational Health. He was equally proficient in both English and Sinhala. His vocabulary, grammar and writing skills were perfect. This he exhibited through the many publications in Occupational Health to which he contributed as an author and editor, which were published by the Department of Community Medicine, Faculty of Medicine, University of Colombo. He was the Course 
Director in the Occupational Health Course conducted by the Community Medicine Department of the Faculty of Medicine-University of Colombo, and was a member of the WHO Expert Panel on Occupational Health.

It was in early 1990's that I came into close association with him. That is when he pulled me out of National Institute of Health Sciences - Kalutara and requested me to enter into Medical Administrative Grade and to accept the post of Deputy Director of the AntiMalaria Campaign when the case load of new cases of Malaria was around 1 million per annum. While he was holding the post of DDG (PHS), he was entrusted to look after all aspects of National Sexually Transmitted Diseases and AIDS Control Programme (NSACP) and was also a member of the National AIDS Committee.

He was an active member of the Board of Study in Community Medicine of the Postgraduate Institute of Medicine (PGIM) of University of Colombo. He was the Course Unit Advisor of the Environmental and Occupational Health module of the MSc Training programme in Community Medicine and a teacher, supervisor and an examiner for the MSc and the MD training programmes in Community Medicine of the PGIM.

He was a member of the Board of Study in Medical Administration of the PGIM and was the Course Unit Advisor for Public Health Administration module of the MSc and the MD training programme in Medical Administration conducted by the PGIM.

He had the rare opportunity of being President of two Colleges, namely President of the College of Community Physicians Sri Lanka in the year 1999- 2000 and President of the College of Medical Administrators of Sri Lanka in 1996. This is a very rare, unique opportunity enjoyed only by a very few medical specialists. He was a joint editor of the publication "Public Health Development in Sri Lanka", the Millennium Supplement of the Journal of the College of Community Physicians of Sri Lanka. He was a Fellow of the College of Community Physicians of Sri Lanka, the College of Medical Administrators of Sri Lanka and the Ceylon College of Physicians. He was also a council member of the Independent Medical Practitioner's Association.
After retirement he made a great contribution to HIV/AIDS Control in Sri Lanka by working as Training Coordinator to the NSACP, IDA/World Bank Health Services Project (1999-2001) and as a Consultant and Management Specialist for the IDA/World Bank assisted National HIV/AIDS prevention project (2002-2006). In the year 2016 he was responsible for editing the publication "Towards Ending AIDS in Sri Lanka, A Road Map" which was a joint publication of the Sri Lanka Medical Association (SLMA) and the National STD/ AIDS Control Programme.

As the final assignment he served as the Assistant Registrar and Acting Registrar of the Sri Lanka Medical Council (SLMC) for nearly 11 years, where I got the opportunity to work with him in the same office after being with him in the Ministry of Health. He retired from the SLMC just ten months ago. Dr. Herath was an exemplary personality, he posed a commanding stature, very outspoken in his conduct, had a good sense of humour and enjoyed company.

He leaves his wife Antoinette - Retired Consultant Rheumatologist of the National Hospital of Sri Lanka, two sons and a daughter, namely, Ravindra, Mahendra and Deepika. His daughter is following his father's footsteps and presently specializing in Community Medicine at the PGIM.

Although your vibrant presence is no more Sir, you leave behind treasured memories among both the young and the old Public Health Community. We miss you very much. But we take comfort that you are safe in the arms of Lord Jesus. Being a devoted Christian, belonging to the Baptist Church of Sri Lanka, I quote an extract taken from the Holy Bible which was printed in the hymn sheet used for the funeral service,

"The Lord will wipe away all the tears from their eyes. There will be no more death, no more grief or crying or pain. All these things are gone forever". (Revelation 21:4)

He was laid to rest on Wednesday, 7 June 2017 amidst a vast distinguished gathering.

May his soul rest in peace! 